\title{
POLA KOMUNIKASI KOMISI PENANGGULANGAN AIDS (KPA) KOTA PEKANBARU DALAM MENSOSIALISASIKAN BAHAYA HIV DAN AIDS KEPADA PENJAJA SEX DAN GAY
}

\section{Rannyta Trijupitasari ${ }^{1}$ \& Muhd Ar. Imam Riauan ${ }^{2}$}

\author{
Program Studi Ilmu Komunikasi Universitas Islam Riau ${ }^{1 \& 2}$ \\ Jl. Kaharudin Nasution no.113 Pekanbaru, 28284 - Indonesia
}

email: rannytatrijupitasari@gmail.com¹& imamriauan@comm.uir.ac.id²

\begin{abstract}
Abstrak
Penelitian ini bertujuan untuk melihat bagaimana pola komunikasi penanggulangan AIDS (KPA) Kota Pekanbaru dalam mensosialisaikan bahaya virus HIV dan AIDS. Metode yang digunakan dalam penelitian ini adalah metode deskriptif kualitatif sedangkan teknik pengumpulan data digunakan adalah observasi,wawancara dan dokumentasi. Subjek penelitian berjumlah 2 orang informan utama dari Komisi Penanggulangan AIDS (KPA), 2 orang informan gay dan 1 orang informan penjaja sex. Hasil penelitian ini menunjukkan bahwa pola komunikasi yang dilakukan Komisi Penanggulangan AIDS (KPA) Kota Pekanbaru dalam mensosialisasikan HIV dan AIDS kepada penjaja sex dan gay ialah dengan cara memberikan penyuluhan kepada penjaja sex dan gay yang bekerja sama dengan instansi atau pun lembagalembaga LSM lainnya dengan tujuan bagaimana untuk memutuskan rantai HIV dan AIDS. Komisi Penanggulangan AIDS (KPA) juga memiliki relawan untuk menyampaikan bahaya virus HIV dan AIDS kepada kelompok yang beresiko tinggi, teman sebaya dan kelompok masyarakat.
\end{abstract}

Kata Kunci : Komisi Penanggulangan AIDS, HIV dan AIDS, Pola Komunikasi.

\begin{abstract}
This study aims to see how communication patterns of AIDS prevention (KPA) Pekanbaru in socializing the danger of HIV and AIDS virus. The method used in this research is descriptive qualitative method while data collection technique used is observation, interview and documentation. Research subjects were 2 main informants from the AIDS Commission (KPA), 2 gay informants and 1 informant of sex workers. The results of this study show that the pattern of communication made by the AIDS Commission (KPA) Pekanbaru City in socializing HIV and AIDS is by giving counseling together with agencies or other NGO institutions with the purpose of how to break the chain of HIV and AIDS. The AIDS Commission (KPA) also has volunteers to convey the danger of HIV and AIDS to high-risk groups, peers and community groups.
\end{abstract}

Keywords: AIDS Prevention Commission, HIV and AIDS, Communication Pattern.

\section{PENDAHULUAN}

Kemajuan dalam berbagai bidang ternyata telah menimbulkan masalahmasalah baru yang dapat menghalangi tercapainya sebuah tujuan.
Perkembangan di era global seperti saat ini komunikasi memiliki peran penting, karena melalui komunikasi manusia akan mendapatkan informasi. Pengetahuan mengenai informasi 
merupakan modal dan kekuatan utama untuk melaksanakan kegiatan dan mencapai keberhasialan.Tanpa informasi seorang pengambil keputusan tidak dapat berbuat efektif, bahkan sering timbul kecemasan dan kekhawatiran serta kecenderungan untuk berbuat kesalahan.

Informasi digunakan manusia untuk mengetahui segala sesuatu yang terjadi baik di dalam maupun di luar lingkungan, terutama dalam suatu lembaga atau perusahaan, informasi memiliki peranan yang yang sangat penting dalam tercapainya tujuan yang diinginkan perusahaan, dan kepentingan bersama dengan publik atau khalayak sasaran. Pada umumnya proses penyampaian informasi atau pesan di dalam suatu lembaga atau perusahaan berlangsung dengan melalui suatu media komunikasi.

Negara Indonesia hingga saat ini masih menghadapi masalah kesehatan yang sangat kompleks dan menjadi beban ganda dalam pembiayaan bidang kesehatan.Penyakit yang diderita oleh masyarakat Indonesia sebagian besar adalah penyakit infeksi menular salah satunya HIV dan AIDS. Penyakit HIV (Human Immunodeficiency Virus) dan AIDS (Acquired Immune Deficiency Syndrome) adalah penyakit yang belum ditemukan obatnya.Para penderita hanya diberikan obat yaitu ARV (Anti Retro Viral) untuk memperlambat penyebaran virus dalam tubuh. Sebagian besar yang menderita HIV dan AIDS diantaranya PSK, pelaku homoseks, pengguna narkoba dan jarum suntik, serta bayi yang lahir dari seorang ibu yang terinfeksi virus HIV dan AIDS. Fakta yang ada menunjukan bahwa kebanyakan dari penderita HIV dan AIDS adalah orang-orang yang perilaku morilnya bertentangan dengannorma agama dan masyarakat, sehingga para ODHA (orang dengan HIV dan AIDS) seringkali mendapatkan perlakuan yang kurang baik serta dekriminatif dari keluarga maupun masyarakat diantaranya hinaan, cemoohan, bahkan sikap tidak suka terhadap ODHA.

Pemahaman yang kurang tentang HIV dan AIDS di masyarakat perlu diminimalisir agar penanganan HIV dan AIDS bukan dengan memerangi penderitanya, tetapi memerangi cara penyebarannya, yaitu melalui penggunaan jarum suntik, pemakaian narkoba dan seks beresiko tinggi.

Pemahaman masyarakat yang belum optimal tentang HIV dan AIDS perlu diminimanlisir agar penanganan HIV dan AIDS bukan dengan cara memerangi ODHA (Orang dengan HIV dan AIDS) tetapi memerangi cara penyebaran virusnya.

Banyak dari masyarakat yang menganggap siapa pun yang sudah terkena HIV dan AIDS harus dijauhi dan kehadirannya pun didalam lingkungan tidak diinginkan . oleh karena itu dibutuhkan perhatian yang serius dari pemerintah untuk mengatasi masalah HIV dan AIDS ini.

Terkait dengan penanggulangan dan pencegahan penyakit HIV/AIDS ini pemerintah daerah Kota/Kabupaten mempunyai tugas untuk melakukannya.Komisi Penanggulangan AIDS (KPA) Kota Pekanbaru merupakan salah satu Komisi Penanggulangan AIDS yang ada untuk tingkat Kabupaten/Kota yang berada di Kota Pekanbaru yang beralamatkan di Jalan Jend.Sudirman No.482. Sebagai lembaga yang bertugas mengendalikan penyebaran HIV dan AIDS di Kota Pekanbaru. Komisi Penanggulangan AIDS (KPA) memiliki peran yang krusial dalam mengurangi kasus kasus yang terjadi yang masih didalam kawasan kota pekanbaru.

Dimana salah satu tujuan dari komisi penanggulangan AIDS (KPA) Kota Pekanbaru adalah meningkatkan upaya pencegahan HIV dan AIDS pada 
semua masyarakat termasuk pada kelompok beresiko tinggi,rentan dan masyarakat umum. Komisi Penanggulangan AIDS (KPA) melakukan pencegahan HIV dan AIDS tersebut juga bekerja sama dengan Dinas Kesehatan, Kantor Kesehatan dan beberapa yayasan atau suatu ikatan perkumpulan.

Komisi Penanggulangan AIDS (KPA) memiliki kegiatan atau program sosialisasi seperti memberikan penyuluhan kepada masyarakat ataupun POCI dan mengkoordinasi program penanggulangannya.POCI (Popolasi Kunci) adalah orang-orang yang beresiko tinggi dan rentan terhadap penularan HIV karena pekerjaan dan lingkungannya serta mereka yang telah terinfeksi HIV yang terdiri dari kelompok populasi yang berperan aktif dalam keberhasilan program pencegahan dan penanggulangan. POCI sendiri pun ada beberapa jenis lagi seperti PS (Penjaja Sex), GWL (Gay,Waria,LSL) dan LBT (Lelaki Beresiko Tinggi).

Ketika Komisi Penanggulangan AIDS (KPA) melakukan kegiatan sosialisasi Komisi Penanggulangan AIDS (KPA) memiliki isi konten sosialisasi mereka sendiri yaitu seperti informasi tentang HIV dan AIDS dan IMS (Infeksi Menular Sex), Pelayanan peer educator, Pendampingan Pada ODHA dan Penguat Kapasitas Komunikasi, mereka menyampaikan sosialisasi dengan durasi \pm 5 jam untuk pertemuan resmi seperti bersama POCI, Tokoh Agama, Tokoh Masyarakat, dan LSM. Sedangkan untuk masyarakat umum seperti untuk acara wirid atau untuk menjadi narasumber suatu acara pihak Komisi Penanggulangan AIDS (KPA) memiliki waktu \pm 3 jam untuk menyampaikan sosialisasi mereka sekaligus dengan berdiskusi kepada audiens.

Korban kasuspenderita HIV dan AIDS selalu memperlihatkan peningkatan yang semakin pesat dengan akselerasi yang semakin mengkhawatirkan.Untuk kasus HIV dari tahun 2000 hingga Agustus 2017 mencapai 1.293 kasus dan untuk kasus AIDS mencapai angka 1.065 kasus.Dan sampai saat ini pun masih banyak masyarakat yang acuh tak acuh dengan virus HIV dan AIDS dan semakin negative terhadap ODHA.

Pra survey dilakukan pada awal bulan Agustus 2016 sampai dengan bulan Agustus 2017 di kantor Komisi Penanggulangan AIDS (KPA) Kota Pekanbaru . Dan berdasarkan hasil pra survey di kantor Komisi Penanggulangan AIDS (KPA) tersebut, komunikasi yang dilakukan antara KPA kepada masyarakat ataupun kepada POCI itu masih kurang efektif. Karena, jika Komisi Penanggulangan AIDS (KPA) melakukan sebuah sosialisasi yang mengetahui itu hanya masyarakat yang akan didatangi tempatnya untuk bersosialisasi, tetapi tidak sampai ke masyarakat yang lainnya, begitu juga untuk komunikasi terhadap POCI. Dan setelah melihat hasil grafik kasus HIV dan AIDS di kota pekanbaru tersebut dapat disimpulkan bahwa semakin banyak masyarakat yang kurang paham mengenai virus HIV dan AIDS yang membuat makin bertambahnya masyarakat atau orang yang terkena penyakit menular HIV dan AIDS ini, maka dari itu penulis tertarik untuk melakukan penelitian dengan judul Pola Komunikasi Komisi Penanggulangan AIDS (KPA) Kota Pekanbaru dalam Mensosialisasikan HIV dan AIDS kepada Penjaja Sex dan Gay.

\section{KERANGKA TEORI}

\section{Komunikasi}

Dalam proses komunikasi, pihak pemberi pesan atau yang disebut juga dengan komunikator akan megharapkan orang lain berpartisipasi atau bertindak sesuai dengan tujuan dan juga pesan yang disampaikan olehnya melalui saluran atau media 
komunikasi kepada pihak penerima pesan atau yang disebut juga dengan komunikan akan membuat efek komunikasi dan mendapatkan umpan balik dari penerima pesan. Jadi dalam kehidupan manusia sangat mustahil manusia akan hidup tanpa adanya komunikasi, baik dalam bentuk komunikasi verbal ataupun komunikasi nonverbal, komunikator menginginkan seluruh pihak yang terlibat dalam proses komunikasinya dapat memahami pesan yang disampaikan olehnya agar proses komunikasi tersebut berjalan efektif.

Dari banyaknya definisi komunikasi tersebut, berikut beberapa definisi para ahli yang bisa dapat dicermati:

1. Harold D. Lasswell. "Cara yang tepat untuk menerangkan suatu tindakan komunikasi ialah menjawab pertanyaan 'Siapa yang menyampaikan?Apa yang disampaikan? Melalui saluran apa? Kepada siapa?dan Apa Pengaruhnya?" (Cangara, 2011: 19)

2. Willbur Schramm. "Komunikasi selalu menghendaki adanya paling setikit tiga unsur, yaitu: sumber (source), pesan (message), dan sasaran (destination)." (Suhandang, 2010:16).

3. Gerald R. Miller. "Komunikasi pada dasarnya penyampain pesan yang disengaja dari sumber terhadap penerima dengan tujuan mempengaruhi tingkah laku penerima" (Sendjaja, 1994: 21)

4. Joseph A. Devito. "Komunikasi mengacu pada tindakan satu orang atau lebih yang mengirim dan menerima pesan, terjadi dalam suatu konteks tertentu, mempunyai pengaruh tertentu, dan ada kesempatan untuk melakukan umpan balik (feedback) yang dipengaruhi oleng lingkungan (konteks) dimana komunikasi itu terjadi (Ruliana, 2014:3)

\section{Fungsi dan Tujuan Komunikasi}

Komunikasi sudah memiliki peranan penting tersendiri didalam kehidupan pada saatsekarang ini, karena teknologi komunikasi saat ini telah semakin maju dan canggih sesuai pada zamannya. Dengan adanya perkembangan komunikasi yang sangat pesat seperti sekarang ini, menjadikan proses pertukaran pesan menjadi lebih cepat,praktis serta lebih efektif lagi.

Menurut Effendy (2003: 55) tujuan komunikasi ialah sebagai berikut;

1. Mengubah Sikap (to change the attitude)

2. Mengubah

Opini/Pendapat/Pandangan (to change the opinion)

3. Mengubah Perilaku (to change the behavior)

4. Mengubah Masyarakat (to change the society)

\section{Pola Komunikasi}

Pola komunikasi berasal dari dua kata yaitu pola dan komunikasi. Dalam Kamus Besar Bahasa Indonesia (KBBI), pola bisa diartikan sebagai model atau bentuk (struktur) yang tetap, sedangkan komunikasi dapat diartikan sebagai pengiriman dan penerimaan pesan atau berita antara dua orang atau lebih sehingga pesan yang dimaksud dapat dipahami. Jika kedua kata tersebut dihubungkan menjadi pola komunikasi, secara ringkas dapat diartikan sebagai bentuk atau struktur penyampaian pesan (KBBI, 2005: 885).Dengan demikian, pola komunikasi disini dapat dipahami sebagai pola hubungan antara dua orang atau lebih dalam pengiriman dan penerimaan pesan dengan cara yang tepat sehingga pesan yang dimaksud dapat dipahami. 
Menurut Joseph A Devito dalam Dhamayanti (2015: 424) ada empat pola komunikasi, yang terdiri dari :

1. Pola Komunikasi Persamaan (Equality Pattern)

Dalam pola ini, tiap individu berbagi hak yang sama dalam kesempatan berkomunikasi. Peran tiap orang dijalankan secara merata.Komunikasi berjalan dengan jujur, terbuka, langsung, dan bebas dari pembagian kekuasaan. Semua orang memiliki hak yang sama dalam proses pengambilan keputusan. Keluarga mendapat kepuasan tertinggi bila ada rasa empati, sikap positif, sikap mendukung dan kesetaraan.

2. Pola Komunikasi Seimbang Terpisah (Balance Split Pattern)

Kesetaraan hubungan tetap terjaga, namun dalam pola ini tiap orang memiliki daerah kekuasaan yang berbeda dari yang lainnya.Tiga orang dilihat sebagai ahli dalam bidang yang berbeda.

3. Pola Komunikasi Tak Seimbang Terpisah (Unbalanced Split Pattern)

Dalam pola ini satu orang mendominasi, satu orang dianggap sebagai ahli lebih dari yang lainnya.Satu orang inilah yang memegang kontrol, seseorang ini biasanya memiliki kecerdasan intelektual lebih tinggi, lebih bijaksana atau berpenghasilan lebih tinggi.

4. Pola Komunikasi Monopoli (Monopoly Pattren)

Satu orang dipandang sebagai pemegang kekuasaan. Satu orang ini lebih bersifat memberi perintah dari pada berkomunikasi.Ia memiliki hak penuh untuk mengambil keputusan sehingga jarang atau tidak pernah bertanya atau meminta pendapat orang lain.

\section{METODE PENELITIAN}

Penelitian ini menggunakan metode penelitian kualitatif. Metode penelitian kualititatif dalam artikel ini digunakan untuk mengetahui pola komunikasi Komisi Penanggulangan AIDS Kota Pekanbaru dalam mensosialisasikan HIV dan AIDS. Informan dalam penelitian ini adalah 2 Orang penanggungjawab kegiatan sosialisasi tentang HIV dan AIDS. 2 orang gay 1 orang pekerja sex komersial dijadikan sebagai informan tambahan. Sedangkan teknik pengumpulan data yang digunakan adalah Observasi, wawancara, dan dokumentasi.

\section{PEMBAHASAN}

Pembahasan penelitian tentang Pola komunikasi Komisi Penanggulangan AIDS (KPA) Kota Pekanbaru dalam mensosialisasikan HIV dan AIDS kepada Penjaja Sex dan Gay.Yang telah dilakukan dari hasil wawancara dan observasi di Komisi Penanggulangan AIDS (KPA) Kota Pekanbaru.Pada bagian ini penulis menyampaikan pembahasan penelitian melalui pola komunikasi yang dipakai.

Dari sudut pandang pola komunikasi, Komisi Penanggulangan AIDS (KPA) Kota pekanbaru memiliki jabatan sebagai pengirim komunikasi yang artinya orang yang menyampaikan pesan. Sedangkan Penjaja Sex dan Gay sebagai penerima pesan yang diberikan oleh Komisi Penanggulangan AIDS (KPA) dalam mensosialisasikan HIV dan AIDS.

\section{Pola Komunikasi Komisi Penanggulangan AIDS (KPA) Kota Pekanbaru dalam "mensosialisasikan HIV dan AIDS kepada Penjaja Sex dan Gay.}

Menurut Kamus Besar Bahasa Indonesia (KBBI) yaitu Pola Komunikasi berasal dari dua kata yaitu pola dan komunikasi.Pola bisa diartikan sebagai model atau bentuk (struktur) yang tetap, sedangkan komunikasi dapat 
diartikan sebagai pengiriman dan penerimaan pesan atau berita antara dua orang atau lebih sehingga pesan yang dimaksud dapat dipahami.Jika kedua kata tersebut dihubungkan menjadi pola komunikasi, secara ringkas dapat diartikan sebagai bentuk atau struktur penyampaian pesan (KBBI, 2005:885).Dengan demikian, pola komunikasi disini dapat dipahami sebagai pola hubungan antara dua orang atau lebih dalam pengiriman dan penerimaan pesan dengan cara yang tepat sehingga pesan yang dimaksud dapat dipahami dan dimengerti. Seperti yang dilakukan oleh Komisi Penanggulangan AIDS (KPA) Kota Pekanbaru dalam mensosialisasikan HIV dan AIDS.

Komisi Penanggulangan AIDS (KPA) Kota pekanbaru bertujuan untuk menanggulangi virus HIV dan AIDS agar tidak semakin berkembang lebih banyak lagi. Agar virus HIV dan AIDS ini tidak semakin berkembang dengan pesat lagi Komisi Peanggulangan AIDS (KPA) melakukan peran mereka untuk memberikan informasi, penyuluhan serta sosialisasi kepada mereka kelompok-kelompok yang beresiko tinggi seperti penjaja sex dan gay, kelompok ODHA, serta masyarakat umum. Dalam hal untuk menyampaikan sebuah informasi ini Komisi Penanggulangan AIDS (KPA) menggunakan bahasa-bahasa serta istilah-istilah yang bisa dengan mudah dimengerti serta dapat dicerna dengan cepat oleh penjaja sex,gay, ODHA ataupun masyarakat. Disini Komisi Penanggulangan AIDS (KPA) tidak menggunakan bahasa medis atau bahasa didunia kedokteran sama sekali, karna jika Komisi Penanggulangan AIDS (KPA) menggunakan bahasa didunia medis maka itu akan sulit diterima oleh atau akan sulit dipahami oleh mereka.

Ini diperkuat oleh (Suranto, 2010: 116) mengatakan kegiatan komunikasi merupakan kunci awal membentuk pola komunikasi. Pola komunikasi adalah suatu kecenderungan gejala umum yang menggambarkan cara berkomunikasi yang terjadi dalam suatu kelompok tertentu Dari proses komunikasi akan muncul pola, model, bentuk dan bagianbagian kecil yang berkaitan dengan proses komunikasi.

Menurut analisis peneliti Komisi Penanggulangan AIDS melakukan sosialisasi dengan pola atau pun model yang berbeda - beda. Tergantung kepada kelompok mana yang akan mereka berikan informasi. Tujuan Komisi Penanggulangan AIDS (KPA) melakukan itu ialah agar audiens atau yang mereka berikan sosialisasi dapat mengerti dan dapat tau beda bagaimana yang sudah tertular virus HIV dan bagaimana yang belum tertular virus HIV. Contohnya jika Komisi Penanggulangan AIDS (KPA) memberikan informasi atau melakukan sosialisasi kepada kelompok penjaja sex dan gay, maka Komisi Penanggulangan AIDS (KPA) lebih mensosialisasikan atau memberikan informasi tentang bagaimana mereka menurunkan resiko agar penjaja sex dan gay tidak semakin beresiko tinngi untuk terkena AIDS, sedangkan kepada masyarakat Komisi Penanggulangan AIDS (KPA) lebih memberikan sosialisasi tentang bagaimana cara menanggulaninya, bagaimana cara agar masyarakat umum tidak sampai terkena virus-virus berbahaya tersebut.

Komisi Penanggulangan AIDS (KPA) melakukan sosialisasi ini tidak hanya sendiri, Komisi Penanggulangan AIDS (KPA) ini juga melakukan sosialisasi HIV dan AIDS bersama dengan instansi atau lembaga-lembaga LSM lain seperti puskesmas, rumah sakit, BNN dan lainnya. Mereka melalukan sosialisasi ini bersama karena ingin mendapatkan sudut pandang yang berbeda dari dunia media seperti dari rumah sakit atau pun dari sudut narkotika, serta apa dampak atau 
bahaya yang akan dihadapi kedepannya. Selain untuk melakukan sosialisasi Komisi Penanggulangan AIDS (KPA) ini pun juga ada melakukan suatu rapat koordinasi atau rapat untuk menyamakan pehaman mereka sekaligus pengambilan keputusan untuk kedepannya, dan rapat ini pun dilakukan setiap bulannya.

Gambar 1

Bentuk Skema Komunikasi Komisi Penanggulangan AIDS (KPA) Kota Pekanbaru

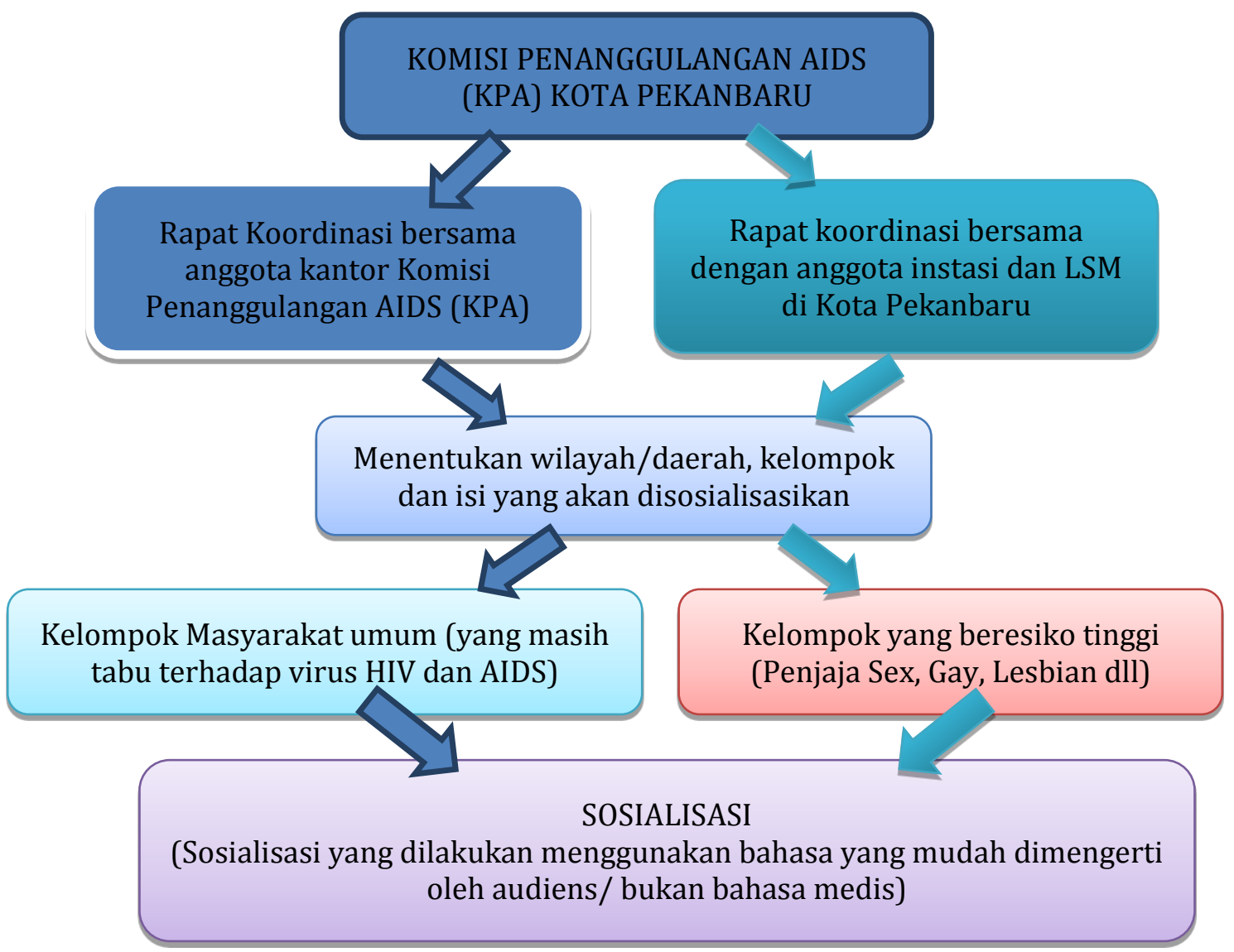

Sumber : Hasil Olahan Peneliti

Pola komunikasi yang dilakukan oleh Komisi Penaggulangan AIDS (KPA) dapat dilihat pada gambar.1 Dari gambar tersebut dapat disimpulkan bahwa pola komunikasi yang dilakukan oleh Komisi Penaggulangan AIDS (KPA) adalah dengan cara melakukan pola komunikasinya dengansosialisasi secara sendiri dan sosialisasi bersama dengan instansi atau pun lembaga-lembaga LSM lainnya. Hal ini dikarenakan Komisi Penanggulangan AIDS (KPA) Kota Pekanbaru bekerja sama dengan instansi atau pun lembaga-lembaga lainnya untuk mengurangi dan menanggulangai virus HIV dan AIDS di Kota Pekanbaru.

Komisi Penanggulangan AIDS (KPA) akan melakukan rapat koordinasi bersama anggota KPA dan juga rapat dengan anggota instansi atau lembagalembaga LSM yang di Pekanbaru seperti puskesmas, rumah sakit dan lainlainnya. Dari rapat itu mereka menentukan wilayah atau daerah yang akan diberikan sosialisasi, menentukan 
isi sosialisasi yang akan disampaikan, serta menentukan kepada kelompok mana mereka akan melakukan sosialisasi sesuai dengan data yang mereka diskusikan atau sesuai dengan kelompok mana yang harus diberi sosialisasi lebih lagi apakah kepada kelompok masyarakat umum atau kepada kelompok yang beresiko tinggi untuk terkena HIV dan AIDS. Setalah mereka melakukan diskusi atau memutuskan kelompok mana yang akan mereka berikan sosialisasi, mereka akan langsung melakukan sosialisasi, dan dalam melakukan sosialisasi tersebut mereka menggunakan bahasa-bahasa yang mudah dimengerti dan yang mudah dipahami oleh para audiens atau oleh para yang mengikuti sosialisasi.

\section{Faktor penghambat Komunikasi Komisi Penanggulangan AIDS (KPA) dalam mensosialisasikan HIV dan AIDS kepada Penjaja Sex dan Gay}

Setiap kegiatan memiliki faktor penghambat dalam pelaksanaannya, baik yang secara, baik berasal dari dalam (internal) maupun dari luar (eksternal)organisasi. Berdasarkan hasil wawancara peneliti kepada informan yakni Koordinator Sub-Sub Recipient (SSR) Bapak Hasan Supriyanto dan Pengelola Program/Monev Bapak Ahmad Bilal mengatakan bahwa faktor penghambat saat menjalankan atau pada saat mensosialisasikan HIV dan AIDS ialah banyak stigma terhadap ODHA, diskriminasi, dana kurang, belum dijadikannya prioritas, serta kurangnya kesadaran.

Berdasarkan hasil wawancara tersebut, peneliti menyimpulkan bahwa pada saat Komisi Penanggulangan AIDS (KPA) melakukan sosialisasi mereka masih banyak mendapatkan faktor penghambat untuk mensosialisasikan HIV dan AIDS tersebut, seperti:

Faktor Internal
1. masih kurangnya dana atau masih minim dana yang mereka terima untuk melakukan sosialisasi.

2. Pembiayaan dari global fun sudah mulai habis, untuk yang dana tahunannya.

Faktor Eksternal

1. Masih banyak stigma dan diskriminasi terhadap ODHA

2. Belum dianggap prioritas sehingga masih tabu untuk diperbincangkan atau masih tabu dalam pembicaraan

3. Lalu masih banyak yang kurang kesadarannya akan melakukan tes HIV dan AIDS.

Faktor pendukung Komunikasi Komisi Penanggulangan AIDS (KPA) dalam mensosialisasikan HIV dan AIDS kepada Penjaja Sex dan Gay

Setiap kegiatan memiliki faktor pendukung dalam pelaksanaannya, baik yang secara, baik berasal dari dalam (internal) maupun dari luar (eksternal)organisasi. Berdasarkan hasil wawancara peneliti kepada informan yakni Koordinator Sub-Sub Recipient (SSr) Bapak Hasan Supriyanto dan Pengelola Program/Monev Bapak Ahmad Bilal mengatakan bahwa faktor pendukung saat menjalankan atau pada saat mensosialisasikan HIV dan AIDS ialah mulai dengan relawan, kepedulian serta tersedianya layanan untuk tes HIV.

Berdasarkan hasil wawancara tersebut, peneliti menyimpulkan bahwa pada saat Komisi Penanggulangan AIDS (KPA) melakukan sosialisasi mereka juga banyak mendapatkan faktor pendukung untuk mensosialisasikan HIV dan AIDS tersebut, seperti:

\section{Faktor Internal}

1. Untuk yang masyarakat adanya kader PIKM (Pusat Informasi Kesehatan Masyarakat), yaitu adanya perpanjangan tangan. 
Kader-kader ini seperti guru,tokoh masyarakat, tokoh agama yang sudah dilatih terlebih dahulu oleh Komisi Penanggulangan AIDS (KPA).

2. Untuk yang ke Populasi Kunci adanya peer educator yaitu perpanjangan tangan juga untuk mereka yang sebaya, peer educator ini juga dilatih terlebih dahulu untuk memberikan informasi ke teman yang lainnya.

Faktor Eksternal

1. Sudah banyaknya relawan dari luar Komisi Penanggulangan AIDS (KPA) yang membantu kami dalam sosialisasi, yang terkadang juga tidak berpikir untuk meminta bayaran

2. Sudah mulai ada kepedulian dari dari media atau pun beberapa masyarakat

3. Dan sudah tersedianya layanan untuk tes HIV dan AIDS di seluruh puskesmas dan rumah sakit di pekanbaru

\section{KESIMPULAN}

Pola komunikasi yang dilakukan Komisi Penanggulangan AIDS (KPA) dalam mensosialisasikan HIV dan AIDS kepada Penjaja Sex dan Gay sudah berjalan dengan sangat baik. Pola komunikasi yang dilakukan Komisi Penanggulangan AIDS (KPA) untuk mensosialisasikan HIV dan AIDS dengan cara bekerja sama dengan instansi dan lembaga-lembaga LSM lainnya. Biasanya Komisi Penanggulangan AIDS (KPA) yang melakukannya sendiri, atau mengajak instansi atau lembaga LSM atau mereka melakukan sesuai dengan pengambilan keputusan bersama instansi dan lembaga-lembaga LSM tersebut.

Faktor penghambat seperti salah satunya ialah masih minimnya dana untuk sosialisasi masih banyaknya stigma negatif dan banyaknya deskriminasi terhadap ODHA, serta kurangnya kesadaran untuk melakukan melakukan tes HIV dan AIDS. Sedangkan faktor pendukungnya ialah Komisi Penanggulangan AIDS (KPA) sudah banyak memiliki relawan untuk melakukan sosialisasi atau membantu untuk mensosialisasikan HIV dan AIDS, memiliki perpanjangan tangan untuk memberikan informasi tentang HIV dan AIDS, dan ditambah lagi saat ini seluruh puskesmas dan Rumah Sakit di Pekanbaru sudah bisa melakukan tes HIV dan AIDS sesuai dengan prosedur yang diberikan puskesmas dan Rumah Sakit tersebut tanpa dipungut biaya sedikitpun.

\section{DAFTAR PUSTAKA}

Cangara, Hafield. (2011). Pengantar Ilmu Komunikasi. Jakarta: Rajawali Pers.

Effendi, Onong Uchjana. (2003). Ilmu Komunikasi Teori dan Praktek. Bandung: Remaja Rosdakarya

Ruliana, Poppy. (2015). Komunikasi Organisasi: Teori dan Studi Kasus. Jakarta: PT. Raja Grafindo Perkasa.

Sendjaja, S.Djuarso. (1994). Teori Komunikasi. Jakarta: Universitas Terbuka.

Suhandang, Kustadi. (2010). Bandung: Pengantar Jurnalistik Seputar Organisasi, Produk dan Kode Etik. Nuansa.

Suranto, A. (2010). Komunikasi Sosial Budaya. Yogyakarta: Graha Ilmu.

Dhamayanti, Meilani. (2015). "Pola Komunikasi Antara Persona Antara Terapis dengan Anak Penderita Autis Dalam Meningkatkan Kemampuan Berinteraksi". Bandung: Fakultas Ilmu Komunikasi Universitas Padjajaran. 